\title{
Perawatan Endodontik Pada Kasus Kombinasi Resorpsi Internal Dan Resorpsi Servikal Gigi Insisivus Sentral Rahang Atas
}

\author{
Marcelina Wijaya $^{1^{*}}$, Diani Prisinda ${ }^{2}$ \\ ${ }^{1}$ Residen Konservasi Gigi, Fakultas Kedokteran Gigi, Universitas Padjadjaran, Bandung, \\ Indonesia \\ ${ }^{2}$ Staf Pengajar Departemen Konservasi Gigi, Fakultas Kedokteran Gigi, Universitas \\ Padjadjaran, Bandung, Indonesia \\ *korespondensi: marcelina18001@ mail.unpad.ac.id
}

\begin{abstract}
ABSTRAK
Pendahuluan: Resorpsi merupakan kondisi terkait proses fisiologis atau patologis yang mengakibatkan hilangnya dentin, sementum, atau tulang karena interaksi terstruktur antara sel inflamasi dan sel resorpsi, dapat terjadi baik internal maupun eksternal, secara bersamaan pada gigi yang sama, muncul sebagai defek yang terpisah atau bergabung. Proses resorpsi dimulai oleh berbagai rangsangan seperti trauma, peradangan kronis pada pulpa terus menerus yang disebabkan oleh faktor bakteri dan perawatan ortodontik. Laporan Kasus: Pasien laki-laki usia 27 tahun datang dengan keluhan gigi atas depan kanan berubah warna sedikit lebih gelap dibandingkan gigi sebelahnya. Gigi tersebut pernah sakit tiba-tiba dan pernah muncul jerawat di sekitar gusinya. Pasien pernah mengalami kecelakaan motor dan gigi depannya terbentur 10 tahun yang lalu, pernah dirawat ortodonti cekat selama 4 tahun. Pemeriksaan radiografis gigi 11 menunjukkan mahkota normal, jumlah akar 1, terdapat radiolusen pada $1 / 3$ hingga $2 / 3$ tengah dinding saluran akar mesial, lamina dura menghilang di periapikal dan pada $2 / 3$ tengah akar dinding mesial, dan terdapat radiolusen berbatas jelas dengan diameter $2 \mathrm{~mm}$. Gigi 11 dilakukan pembukaan akses kavitas, finishing menggunakan nikel titanium rotary ProTaper Gold (Dentsply), irigasi dengan EDTA 17\% dan $\mathrm{NaOCl} 5,25 \%$ serta aktivasi menggunakan ultrasonik (Ultra X, Eighteeth), pemberian medikamen antar kunjungan kalsium hidroksida, selanjutnya pengisian saluran akar dengan teknik warm vertical condensation. Restorasi pasca endodontik yaitu resin komposit direk dengan resin fiber construct (Kerr). Simpulan: Perawatan endodontik kombinasi resorpsi internal dan resorpsi servikal gigi insisivus sentral rahang atas pada kasus ini memperlihatkan keberhasilan yang baik.
\end{abstract}

Kata Kunci : Perawatan endodontik, resorpsi servikal, resorpsi internal, warm vertical condensation, kalsium hidroksida 


\title{
Endodontic Treatment on Central Incisor Maxilla with Internal Resorption and Cervical Resorption
}

\begin{abstract}
Introduction: Root resorption is a condition associated with either physiological or a pathological process resulting in a loss of dentin, cementum, or bone as a result of interactions between inflammatory cells and resorption cells, may occur both internally and externally, simultaneously in the same tooth, revealed as separate or combine defects. The process of resorption is initiated by various stimuli including trauma, chronic inflammation of the pulp caused by bacteria and orthodontic treatment. Case Report: a 27 years old male patient complaint of discoloration on the right upper front tooth. The tooth had spontaneous pain and appear swelled around the gingiva of the teeth. Patient had a motorbike accident and hits his front teeth 10 years ago and also had a history of fixed orthodontic treatment for the past 4 years. Radiographic examination by intraoral periapical radiograph 11 revealed normal crown, one apex, radiolucent from coronal third and extending toward apical two third, lamina dura dissappeared in periapical and apical two third of the mesial wall, and there was a radiolucent with $2 \mathrm{~mm}$ diameter on apical. Access opening was made, finishing was done using rotary nickel titanium ProTaper Gold (Dentsply), canal was irrigated with 17\% EDTA and $5.25 \%$ NaOCl activated using ultrasonic (UltraX, Eighteeth), calcium hydroxide dressing was placed intraapointment, root canal was then obturated with warm vertical condensation technique. Direct resin composite with resin fiber construct (Kerr) for post endodontic restoration. Conclusion: Endodontic treatment of combined internal resorption and cervical resorption on maxillary central incisors in this case has shown good success.
\end{abstract}

Keywords: Endodontic treatment, cervical resorption, internal resorption, warm vertical condensation, calcium hydroxide 


\section{PENDAHULUAN}

Resorpsi merupakan kondisi terkait proses fisiologis atau patologis yang mengakibatkan hilangnya dentin, sementum, atau tulang karena interaksi terstruktur antara sel inflamasi dan sel-sel resorpsi (osteoklas, odontoklas, atau dentinoklas) dan jaringan keras, di inisiasi oleh cedera pada jaringan non-mineral yang menutupi permukaan eksternal akar (precementum) atau permukaan internal saluran akar (predentin). ${ }^{1}$ Resorpsi dapat terjadi baik internal maupun eksternal, secara bersamaan pada gigi yang sama, muncul sebagai defek yang terpisah atau bergabung. Proses resorpsi dimulai oleh berbagai rangsangan seperti trauma, peradangan kronis pada pulpa terus menerus yang disebabkan oleh faktor bakteri dan perawatan ortodontik. ${ }^{2}$ Klasifikasi resorpsi dibagi menjadi resorpsi internal yang terdiri dari inflammatory dan replacement, dan resorpsi eksternal yaitu resorpsi permukaan eksternal, resorpsi servikal invasif, resorpsi akar inflamasi, ankilosis, dan resorpsi replacement. ${ }^{3}$

Resorpsi internal inflammatory dapat terjadi sebagai akibat kerusakan predentin baik oleh trauma akibat iritasi fisik atau kimiawi atau oleh infeksi bakteri pada inflamasi pulpa kronis. Pada lesi resorpsi internal inflammatory progresif aktif, saluran akar koronal ke lesi resorptif biasanya nekrotik, sementara di apikal pulpa sangat penting untuk menyediakan nutrisi ke odontoklas sehingga memungkinkan lesi resorptif berkembang. Namun, jika gigi kehilangan vitalitas, maka perkembangan resorpsi akan berhenti. ${ }^{4}$ Tanda dan gejala klinis biasanya didiagnosis pada lesi lanjut. Pada kasus lanjut dengan saluran akar nekrotik yang terinfeksi, mungkin ada gejala dan atau tanda periodontitis periapikal (misalnya, perubahan warna, sinus, nyeri tekan saat palpasi dan atau perkusi). ${ }^{3}$

Resorpsi servikal invasif merupakan bentuk resorpsi eksternal gigi yang berbahaya dan agresif dengan karakteristik yaitu lokasinya berada di servikal akar gigi dan tidak ada keluhan sakit pada tahap awal sehingga sulit didiagnosis. Namun, dalam kasus yang lebih lanjut ketika ada keterlibatan pulpa mungkin ada gejala pulpitis ireversibel dan atau periodontitis apikal. Penyebab kondisi ini masih tidak jelas, Heithersay dalam analisis faktor predisposisi dari 222 pasien dengan 257 gigi resorpsi servikal invasif, melaporkan bahwa perawatan ortodontik $(24,1 \%)$ adalah faktor yang paling umum, dan trauma $(15,1 \%)$ adalah paling umum kedua. ${ }^{5}$

Gambaran klinis dari resorpsi internal maupun eksternal hampir sama dan perbedaan tampak hanya terkait dengan tempat resorpsi. Diagnosis resorpsi yang akurat dan dini sangat penting untuk keberhasilan perawatan dengan memiliki pengetahuan terhadap berbagai jenis resorpsi sehingga dapat mendiagnosis dengan benar dan dapat memberikan perawatan yang tepat. Tujuan penulisan laporan kasus ini yaitu untuk menjelaskan perawatan saluran akar gigi insisivus sentral rahang atas dengan kombinasi resorpsi internal dan resorpsi servikal.

\section{LAPORAN KASUS}

Pasien laki-laki berusia 27 tahun datang ke klinik konservasi RSGM FKG UNPAD dengan keluhan gigi atas depan kanan berubah warna sedikit lebih gelap dibandingkan gigi sebelahnya. Gigi tersebut pernah sakit tiba-tiba dan pernah muncul jerawat di sekitar gusinya. Pasien pernah mengalami kecelakaan motor dan gigi depannya terbentur 10 tahun yang lalu. Riwayat dental pasien pernah dirawat ortodonti cekat selama 4 tahun dan tidak memiliki riwayat penyakit sistemik. Pasien ingin giginya dirawat sampai selesai.

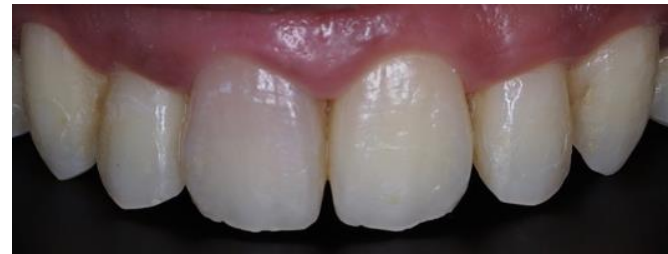

(a)

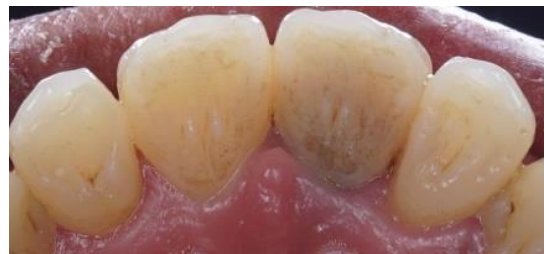

(b)

Gambar 1. Foto klinis awal gigi 11. (a) labial, (b) palatal. 
Hasil pemeriksaan fisik dan tanda vital menunjukkan tekanan darah 120/70 mmHg, pernafasan $24 \mathrm{x} /$ menit, dan nadi $76 \mathrm{x} /$ menit. Pemeriksaan ekstra oral menunjukkan wajah simetris, otot bibir normal, bibir tidak ada kelainan, TMJ dalam batas normal, kelenjar limfe tidak teraba dan tidak sakit. Pemeriksaan intra oral menunjukan gigi 11 terdapat perubahan warna pada labial (gambar 1a) dan servikal palatal (gambar 1b), tidak terdapat karies, dan posisi gigi normal. Pemeriksaan objektif gigi 11, tes dingin menunjukkan respon negatif, perkusi menunjukkan respon positif, palpasi menunjukkan respon negatif, tidak terdapat kegoyangan, serta jaringan sekitarnya tidak ada kelainan, probing pada labial bagian mesial, tengah, dan distal menunjukkan hasil 4, 3, $3 \mathrm{~mm}$ dan probing pada palatal dari mesial tengah dan distal menunjukkan 4, 3, $3 \mathrm{~mm}$. Pemeriksaan radiografis memperlihatkan mahkota dalam batas normal, akar satu, terdapat radiolusen pada 1/3-2/3 tengah dinding saluran akar mesial, lamina dura menghilang di periapikal dan pada $2 / 3$ tengah akar dinding mesial, periapikal terdapat radiolusen berbatas jelas dengan diameter $2 \mathrm{~mm}$. Diagnosis yang ditegakkan pada gigi 11 adalah nekrosis pulpa dengan periodontitis apikal asimtomatik (AAE, 2013) disertai kombinasi resorpsi akar internal inflamasi dan resorpsi servikal invasif. Rencana perawatan yang akan dilakukan yaitu scalling dan Dental Health Education (DHE), perawatan saluran akar, kemudian restorasi paska endodontik yaitu resin komposit direk dengan resin fiber construct (Kerr).

\section{Kunjungan I}

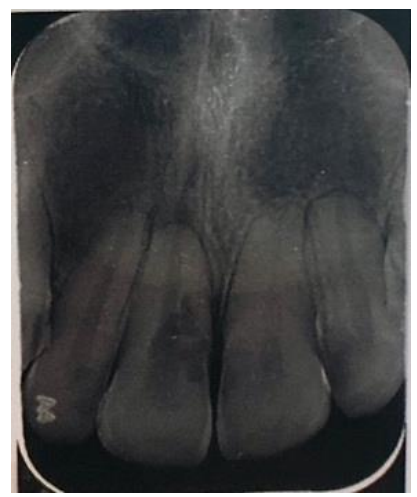

Gambar 2. Foto radiografis gigi 11.

Pasien datang dan dilakukan pemeriksaan subjektif, objektif, pengambilan foto klinis dan radiografi, penentuan diagnosis dan rencana perawatan. Pasien diberikan informasi mengenai keadaan giginya dan seluruh tindakan perawatan yang akan dilakukan serta komplikasi yang mungkin terjadi. Setelah mengerti dan setuju, pasien kemudian diminta untuk menandatangani lembar informed consent.

Tindakan scaling dilakukan pada seluruh gigi dan diberikan DHE. Isolasi gigi 11 dengan rubber dam, preparasi akses koronal dengan menggunakan endo acces bur (Dentsply) sampai menembus kamar pulpa dan seluruh atap kamar pulpa terambil hinga orifis dan bagian yang mengalami resorpsi terlihat dengan jelas kemudian membentuk preparasi akses kavitas dengan menggunakan bur endo Z (Dentsply) (Gambar 3A). Irigasi saluran akar menggunakan larutan $\mathrm{NaOCl}$ 5,25\% kemudian penentuan Initial Apical File (IAF) dengan K-File nomor 25 (Mani, Sybron) selanjutnya dilakukan pengukuran panjang kerja menggunakan apex locator (Apex ID) dengan $K$-File no 25 dan didapatkan panjang saluran akar $24 \mathrm{~mm}$.

Cleaning dan shaping dilakukan pada saluran akar menggunakan file ProTaper Gold (Gambar 3B,C). Master apical file saluran akar adalah F5 (40.06) ProTaper Gold (Dentsply) (Gambar 3D). Irigasi dilakukan menggunakan EDTA 17\% untuk menghilangkan smear layer dan $\mathrm{NaOCl} 5.25 \%$ dengan bilasan aquadest di setiap pergantian cairan irigasi (Gambar 3E). Cairan yang ada di saluran akar saat irigasi diaktivasi menggunakan ultrasonik (UltraX, Eighteeth) (Gambar 3F). Saluran akar kemudian dikeringkan menggunakan paper point 
kemudian diaplikasikan medikamen antar kunjungan digunakan $\mathrm{Ca}(\mathrm{OH})_{2}$ (Ultracal, Ultradent) (Gambar 3G) dan ditutup dengan tambalan sementara.
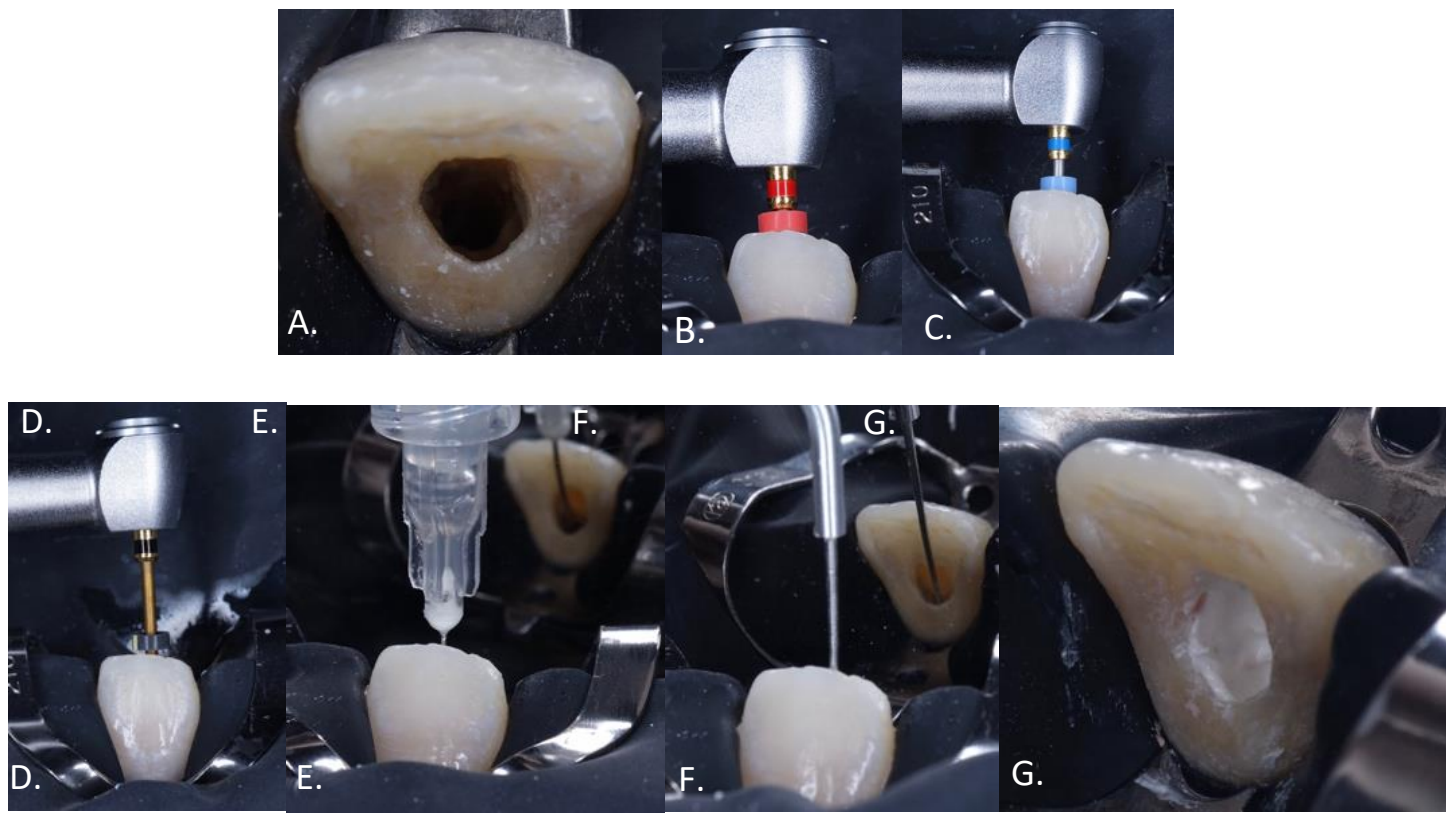

Gambar 3. A, preparasi akses kavitas. B dan C, Cleaning dan shaping. D, Master apical file. E, Irigasi saluran akar. F, Aktivasi ultrasonik. G, Medikasi intrakanal.

\section{Kunjungan II}

Pemeriksaan objektif dan subjektif dilakukan, kemudian gigi diisolasi menggunakan rubber dam. Tambalan sementara dibuka dan $\mathrm{Ca}(\mathrm{OH})_{2}$ dibersihkan menggunakan aquadest dan $\mathrm{NaOCl} 5,25 \%$ yang diaktivasi dengan ultrasonik (UltraX, Eighteeth) (Gambar 4A) lalu dikeringkan menggunakan paper point, selanjutnya aplikasikan kembali $\mathrm{Ca}(\mathrm{OH})_{2}$ ke semua saluran akar dan bagian yang mengalami resorpsi (Gambar 4B). Foto ronsen periapikal dilakukan untuk melihat perubahan pada bagian periapikal dan juga memastikan $\mathrm{Ca}(\mathrm{OH})_{2}$ sampai ke daerah yang mengalami resorpsi (Gambar 4C).
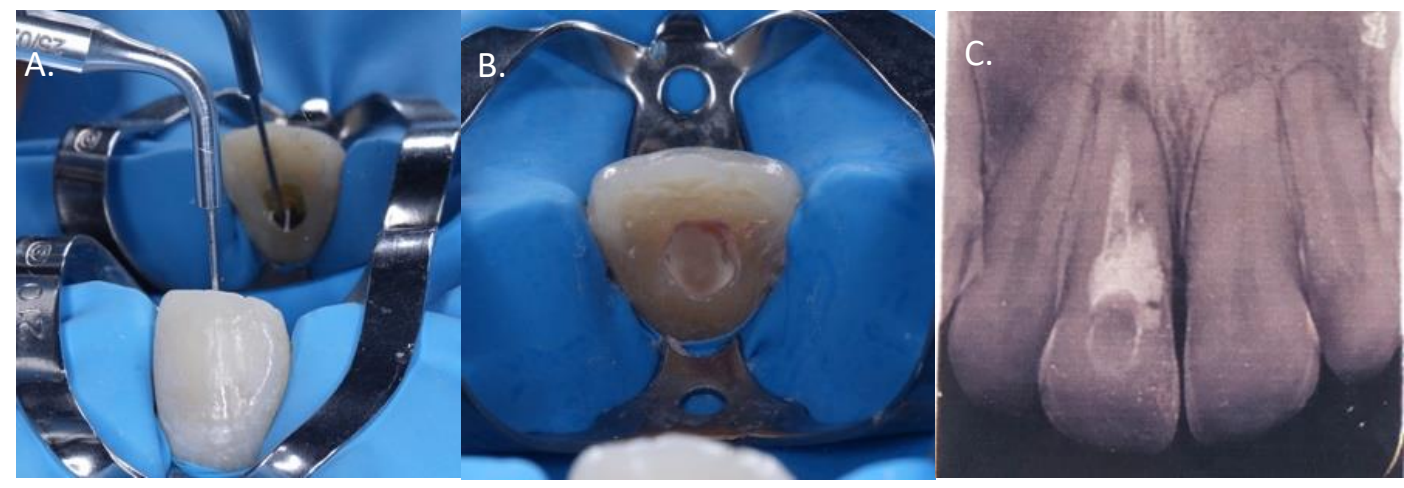

Gambar 4. A, Irigasi dan aktivasi ultrasonik. B, Medikamen intrakanal. C, foto ronsen periapikal dengan medikamen intrakanal.

\section{Kunjungan III}

Pasien kembali ke RSGM kemudian dilakukan pemeriksaan objektif dan subjektif dilakukan, kemudian gigi diisolasi menggunakan rubber dam. Tambalan sementara dibuka dan $\mathrm{Ca}(\mathrm{OH})_{2}$ dibersihkan seluruhnya menggunakan aquadest dan $\mathrm{NaOCl} 5,25 \%$ yang diaktivasi dengan ultrasonik (UltraX, Eighteeth) lalu dikeringkan menggunakan paper point (Gambar 5A), selanjutnya dilakukan uji coba gutta percha dengan memasukkan gutta percha primary 
pada saluran akar dan dilakukan foto ronsen periapikal.

Pengisian saluran akar pada gigi 11 menggunakan gutta percha points F5 ProTaper (Dentsply) dan sealer GuttaFlow (Coltene) dengan teknik warm vertical condensation hingga 2mm dari CEJ ke arah apikal (Gambar 5B) kemudian ditutup dengan Glass Ionomer Fuji VII $(G C)$ dan ditutup tambalan sementara. Setelah itu kembali dilakukan pemeriksaan radiografi (Gambar 5C).

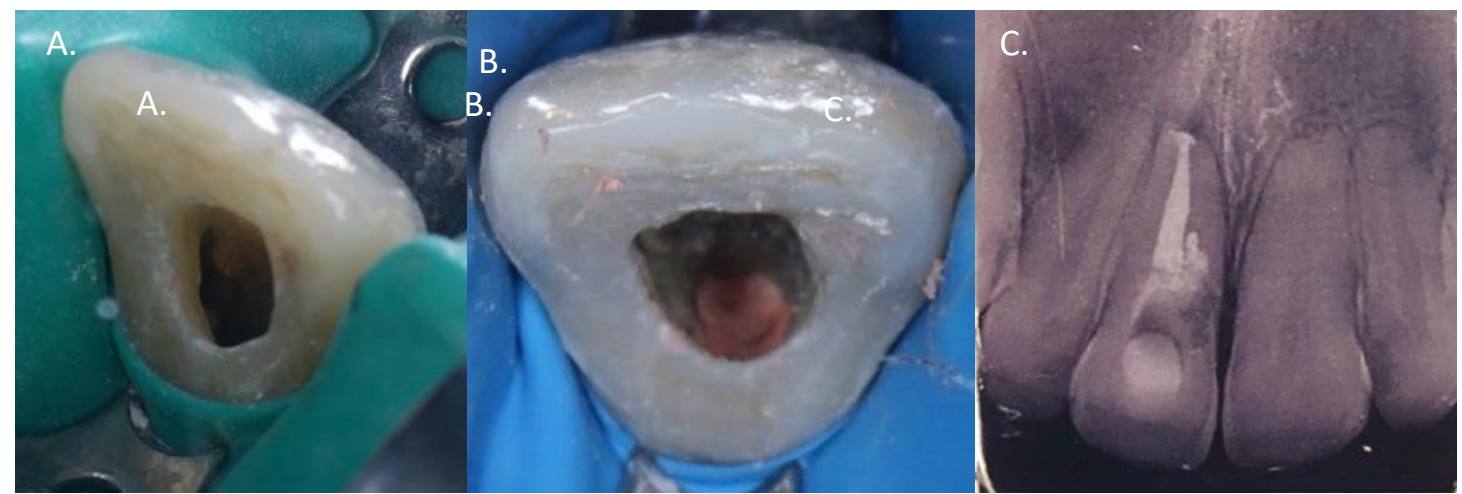

Gambar 5. A, setelah kavitas di keringkan. B, setelah obturasi. C, foto ronsen periapikal setelah obturasi.

\section{Kunjungan IV}

Kontrol pasca obturasi dan pengaplikasian resin fiber reinforced (Construct, Kerr) ke daerah yang resorpsi sampai sebatas singulum, kemudian komposit packable hingga semua kavitas tertutup. Cara penggunaan resin fiber constratc (Kerr) yaitu setelah tumpatan sementara dilepas, kavitas di irigasi dengan salin dan keringkan dengan semprotan udara ringan serta gunakan cotton pellet dan paper point untuk memastikan kavitas terutama bagian mesial yang mengalami resorpsi dalam kondisi kering. Kavitas di etsa dan bonding dengan Scothbond Universal Adhesive (3M) kemudian lakukan penyinaran. Construct fiber warna natural berukuran $2 \mathrm{~mm}$ dipotong sepanjang $2 \mathrm{~cm}$, letakkan di pelat kaca kemudian aplikasikan resin kerr ke fiber. Resin dimasukkan ke dalam kavitas dengan menggunakan plastic filling instrument, kondensasi ke mesial dengan plugger berukuran kecil sampai padat, kemudian padatkan kembali di bagian tengah kavitas sampai sebatas singulum, selanjutnya lakukan penyinaran selama 40 detik dan aplikasikan resin komposit packable sampai dengan kavitas tertutup sempurna. Tahap selanjutnya adalah aplikasi gliserin dan lakukan penyinaran selama 20 detik. Pemolesan dilakukan pada permukaan komposit dengan bur poles berwarna merah muda dan abu-abu (Eve diacomp), dilanjutkan cek oklusi dan artikulasi dengan menggunakan kertas artikulasi.

\section{PEMBAHASAN}

Pada praktik endodontik, resorpsi akar adalah salah satu tantangan yang sering dihadapi. Deteksi dini dan diagnosis banding yang akurat adalah faktor penting yang menentukan keberhasilan klinis kasus dengan resorpsi. Jika gigi dapat direstorasi dan memiliki prognosis yang reasonable, perawatan saluran akar adalah pilihan perawatan. Tujuan dari perawatan saluran akar adalah untuk menghilangkan semua jaringan vital dan nekrotik, untuk memastikan bahwa sel-sel resorpsi dilisiskan dan untuk mendisinfeksi serta obturasi sistem saluran akar. Prosedur ini mejadi sulit karena sifat infiltratif pada lesi resorpsi yang parah memiliki bentuk yang tidak beraturan dan saluran-saluran kecil yang terkadang saling berhubungan membuat desinfeksi menyeluruh dari saluran akar menjadi sulit, sehingga pendekatan kemo-mekanis bersama dengan medikamen antibakteri intrakanal dianjurkan untuk membuat saluran akar bebas dari bakteri. 
Pada kasus ini dapat disimpulkan gigi 11 mengalami kombinasi resorpsi internal akar dan resorpsi servikal. Pada gambaran radiografi terlihat lokasi resorpsi berada di sekitar servikal akar gigi, adanya radiolusen tidak beraturan asimetris pada dinding mesial kamar pulpa meluas sampai ke 1/3 koronal akar, dan batas lesi tidak beraturan tampak superimposed dengan outline rongga pulpa sehingga disimpulkan gigi tersebut mengalami resorpsi servikal. Kemudian terdapat radiolusen membulat pada kamar pulpa diding distal dan saluran akar tampak membesar, pada dinding mesial saluran akar terlihat sedikit membulat sehingga dicurigai pasien juga mengalami resorpsi internal. Pasien memiliki riwayat trauma dan pemakaian ortodontik cekat. Trauma sebagai faktor utama dan gaya ortodontik yang berlebihan sebagai faktor predisposisi menginisiasi terjadinya respon inflamasi.

Kecelakaan motor yang dialami pasien 10 tahun yang lalu menyebabkan trauma pada gigi depannya sehingga terjadi kerusakan pada ligamen periodonsium servikal serta hilangnya lapisan presementum akar. Tekanan dari piranti ortodontik cekat yang berlebihan pada daerah servikal menjadi stimuli berlanjutnya proses resorpsi menjadi lebih invasif. Daerah sekitar menjadi nekrotik dan insiasi proses inflamasi menstimulasi perkembangan sel osteoklas dan menempel pada permukaan akar servikal. Bakteri masuk ke tubuli dentin menembus pulpa melalui sulkus periodontal yang selanjutnya menembus predentin mengakibatkan terbukanya pulpa. Degenerasi odontoblas dan inflamasi pulpa serta aktivasi odontoklas terjadi akibat dari stimulasi bakteri yang terus menerus. Jaringan ikat bermetaplasia membentuk jaringan granulasi menggantikan dentin yang teresorpsi menekan dinding pulpa akar sehingga terjadi resorpsi internal pada kamar pulpa dan saluran akar. Infeksi terus berkembang membuat seluruh pulpa mengalami nekrosis kemudian berlanjut menjadi periodontitis apikalis. ${ }^{12}$ Perawatan endodontik non bedah menjadi pilihan perawatan pada kasus ini untuk mencegah perkembangan resorpsi lebih lanjut serta dilakukan perbaikan defek resorpsi.

Desinfeksi saluran akar menggunakan larutan dan zat dengan sifat antibakteri dan pelarut jaringan disebut "chemical debridement" merupakan bagian penting dari preparasi dan instrumentasi saluran akar. Prosedur ini disebut sebagai "chemo-mechanical". Desinfeksi yang adekuat sangat penting dalam keberhasilan perawatan endodontik dengan tujuan utama mengeliminasi mikroflora intrakanal serta komponennya yang infeksi maupun nekrotik. Bahan irigasi yang paling umum digunakan yaitu $\mathrm{NaOCl}$ (sodium hipoklorit) dan EDTA (ethylene diamine tetra-acetic acid). $\mathrm{NaOCl}$ merupakan antimikroba yang efektif melawan berbagai macam organisme terkait endodontik sedangkan EDTA mampu menghilangkan smear layer sehingga membuka tubulus dentin. Direkomendasikan irigasi menggunakan EDTA 15-17\% diikuti instrumentasi. Waktu irigasi harus 20-30 detik untuk setiap saluran akar. Penggunaan instrument ultrasonik terbukti meningkatkan kemampuan menghilangkan debri organik dan biofilm dari saluran akar. Pada kasus resorpsi dengan defek yang tidak beraturan menyulitkan akses untuk instrumentasi normal dan irigasi pasif, sehingga aktivasi ultrasonik dengan irigasi menjadi langkah penting pada perawatan kasus-kasus ini. Meskipun tindakan ini diterapkan, banyak literatur mengatakan bahwa masih terdapat mikroorganisme yang hidup dalam saluran akar setelah dilakukan preparasi kemomekanis pada kunjungan pertama. Pada kasus ini digunakan bahan irigasi $\mathrm{NaOCl}$ 5,25\% selama 20 detik serta penggunaan instrumen ultrasonik agar membantu penetrasi irigasi endodontik ke seluruh saluran akar dan juga digunakan EDTA $17 \%$ selama 20 detik pada pergantian instrumentasi.

Berbagai macam medikamen intrakanal yang digunakan antar kunjungan untuk mendesinfeksi saluran akar salah satunya adalah kalsium hidroksida. $\mathrm{Ca}(\mathrm{OH})_{2}$ efektif menghambat pertumbuhan bakteri dalam saluran akar. Aktivitas antimikroba kalsium hidroksida didapatkan dari $\mathrm{pH}$ basa, dan dapat membantu melarutkan sisa-sisa jaringan nekrotik serta bakteri dan produknya. ${ }^{13}$ Sehingga pada kasus ini digunakan medikamen intrakanal kalsium hidroksida sebanyak 2x kunjungan dengan jarak 2 minggu agar didapatkan saluran akar yang bebas dari bakteri. 
Salah satu tujuan dasar perawatan endodontik adalah untuk mengisi saluran akar yang telah di desinfeksi sebelumnya. Pada kasus kerusakan jaringan keras karena resorpsi sulit untuk melakukan obturasi yang adekuat sehingga untuk mengisi defek resorpsi, bahan pengisi saluran akar harus dapat mengalir. Selama bertahun-tahun gutta percha telah digunakan sebagai bahan obturasi saluran akar, dengan dipanaskan gutta percha dapat mengisi area saluran akar lebih banyak dan lebih baik. Saat ini heated vertical compaction menggunakan guttap percha point menjadi gold standard untuk obturasi saluran akar. Pada kasus ini pengisian saluran akar dilakukan dengan menggunakan gutta percha F5 ProTaper (Dentsply) dan sealer GuttaFlow (Coltene) dengan teknik warm vertical condensation. Kontrol gigi 11 dilakukan setelah pengisian saluran akar selama 6 bulan dilanjutkan dengan restorasi akhir. Rencana restorasi akhir yang akan dilakukan pada pasien ini yaitu restorasi direk resin komposit dengan resin fiber constract (Kerr) yang akan diaplikasikan pada area resorpsi di mahkota bagian mesial hingga sebatas singulum dengan tujuan untuk memperkuat struktur gigi mahkota kemudian kavitas di tutup dengan resin komposit.

\section{SIMPULAN}

Perawatan saluran akar yang efektif pada resorpsi akar memerlukan pengetahuan mengenai etiologi dan patogenesis sehingga dapat dilakukan pemilihan terapi yang tepat agar didapatkan perawatan yang sukses. Kriteria keberhasilan perawatan didefinisikan sebagai penyembuhan periapikal dan periradikular tanpa tanda resorpsi, asimptomatik, tidak terjadi infeksi berulang, dan tidak ada kegoyangan gigi. Perawatan endodontik kombinasi resorpsi internal dan resorpsi servikal gigi insisivus sentral rahang atas pada kasus ini memperlihatkan keberhasilan yang baik.

\section{DAFTAR PUSTAKA}

1. Mehra N, Yadav M, Kaushik M, Roshni R. Clinical Management of Root Resorption: A Report of Three Cases. Cureus. 2018;10(8). doi:10.7759/cureus.3215

2. Baumann MA, Rudolf Beer. Endodontology. 2nd, illustr ed. (Baumann MA, ed.). Thieme, 2010; 2013. https://books.google.co.id/books/about/Endodontology.html?id=EzgBuAAACAAJ\&redi r_esc=y.

3. Patel S, Saberi N. The ins and outs of root resorption. Br Dent J. 2018;224(9):691-699. doi:10.1038/sj.bdj.2018.352

4. Nilsson E, Bonte E, Bayet F, Lasfargues JJ. Management of internal root resorption on permanent teeth. Int J Dent. 2013;2013(August). doi:10.1155/2013/929486

5. Rotondi O, Waldon P, Kim SG. The Disease Process, Diagnosis and Treatment of Invasive Cervical Resorption : A Review. 2020.

6. Bergheim B, Rahul M, Vijay M, Shraddha K. Internal resorption : A review \& case report. Endodontology. 2010;22:100-108.

7. Darcey J, Qualtrough A. Resorption: Part 2. Diagnosis and management. Br Dent J. 2013;214(10):493-509. doi:10.1038/sj.bdj.2013.482

8. Bansode P V, Pathak SD, Wavdhane MB, Birage PP. Root Resorption and It's Management: a Review Article. IOSR J Dent Med Sci e-ISSN. 2019;18(1):63-69. doi:10.9790/0853-1801016369

9. Bjørndal L, Kirkevang L-L, Whitworth J, eds. Textbook of Endodontology. 3rd ed. WileyBlackwell; 2018. doi:10.1017/CBO9781107415324.004

10. Patel S, Mavridou AM, Lambrechts P, Saberi N. External cervical resorption-part 1: histopathology, distribution and presentation. Int Endod J. 2018;51(11):1205-1223. doi:10.1111/iej.12942 